\title{
Use of Waste Material in Concrete
}

\author{
Salman', Mr Chitranjan Kumar² \\ 1Student, ${ }^{2}$ Assistant Professor \\ Department of Civil Engineering, Al-Falah School of Engineering and Technology, \\ Al-Falah University Dhauj, Faridabad, Haryana, , India
}

\begin{abstract}
Concrete is one of the most widely used construction materials in the world. However, the production of Portland cement, an essential constituent of concrete, leads to the release of significant amount of CO2, a greenhouse gas; one ton of Portland cement clinker production is said to creates approximately one ton of $\mathrm{CO} 2$ and other greenhouse gases (GHGs). Environmental issues are playing an important role in the sustainable development of the cement and concrete industry [Naik and Moriconi, 2005].There is a need to replace a part of cement by some pozzolanic material to reduce the consumption of cement and the environmental pollution can be checked to some extent. Some of the industrial wastes like fly ash, silica fume, blast furnace slag etc have already established their usage in concrete. Recently the research has shown that the waste glass can be effectively used in concrete either as glass aggregate or as a glass pozzolana. Waste glass when grounded to a very fine powder shows some pozzolanic properties because of silica content. Therefore the glass powder to some extent can replace the cement and contributes for thestrength development and also enhances durability characteristics [Chikhalikar S.M. and Tande S.N., 2012]. Demand for recycled glass has considerably decreased in recent years, particularly for mixed-glass. Glass is cheaper to store than to recycle, as conditioners require expenses for the recycling process. There are several alternatives for the reuseof composite-glass. According to previous studies, all these applications, which require pre-conditioning and crushing,are more or less limited and unable to absorb all the quantities of waste glass available. In order to provide a sustainable solution to glass storage, a potential and incentive way would be to reuse this type of glass in concrete [Idir R,2009].This paper present literature review on replacement of cement by waste glass powder which includes current and future trends of research on the use of crushed glass powder in Portland cement concrete.
\end{abstract}

\section{INTRODUCTION}

In the world of construction and the demand of major construction projects use of cements is very often as we all know that cement composed of many natural substances like silica, alumina which are very rare substances hence in our study all efforts are made to use glass powder as a partial replacement of cement (upto 30\%) which helps in use of waste material like glass powder as a part of cement. By using glass powder sustainability in construction can be achieved.. Glass is a type of material which can by classify as an inert material and can be reuse and recycled time to time.. Being chemically classified as amorphous with large amount of silica content which makes glass behavior as pozzolanic only when its particles size is not more than $75 \mu \mathrm{m}$. Many research have proved that glass powder play no role to alkali- silica reaction. Further for balancing green houses gases researches are made which shows that glass powder can be partially replaced with conventional materials used in concrete formation. Critical thing in using glass in concrete is only the reaction that takes place between silica glass particles and alkali in pores of concrete Silicate reaction are not so good for the stability of concrete, until efforts are not made to minimize the effect.. Alkali Silica Reaction(ASR) can be minimized by adding admixtures in concrete, commonly used admixtures are Pulverized fuel Ash(PFA) and Silica Fume.. Many well known studies shows that use of admixtures like PFA and Silica Fume in concrete can increase the stability.. The conclusion is that glass powder has high silica content and can be used as a raw material in cement production.

Good Results have been noticed while using glass powder as a replacement of cement. Partial replacement helps in getting the stability of cement components.. A thick and consistent component is formed when mixed raw glass powder is used as thorough replacement of cement, which helps in reducing the moisture absorption and results in increasing the durability of cement components. When glass powdermixed with the cement and replaced around 20\% of cement component enhances the moisture barrier, durability's and mechanical performance of concrete.

\subsection{GENERAL POZZOLANA INFORMATION:}

The pozzolanic materials are vital siliceous or aluminous component which itself having not any cementitious properties, which made reaction with with calcium hydroxide $[\mathrm{Ca}(\mathrm{OH}) 2]$ liberated in the hydration process to form compounds possessing cementitious properties. The pozzolanic materials can be used in cement with for 10 to 35 percent. This addition of pozzolanic material makes concrete more stable The overall stability and workability of concrete depend on the aggregates used in concrete. Pozzolanic material makes concrete resistant to chemical attack and strenth gain reduced to some extent than conventional concrete. Deleterious chemical constituents include sulfides (turn concrete green), sulfates (can cause delayed expansion), and alkalis (which add more alkali to concrete which creates higher risk of ASR over the life of the concrete). A pozzolana is de-polymerizes at the $13.5 \mathrm{pH}$ environment of freshly poured concrete to go into solution to ultimately react with the lime in solution to form additional CSH binder. Which makes pozzolana stable constitute for Cement. Similarly, fly ashes may vary in composition and gradation and contain majorly carbon and sulphates or lime, which leads to non desirable effects in concrete may. Silica fume are also in use in cement, they consume more water but they have great impact on durability and stability of concrete. 


\subsection{RECYCLED GLASS AS A POZZOLANA:}

The use of recycled glass in very critical from chemical point of view. In earlier studies glass fiber is very commonly used in concrete as a reinforcement. The use of glass powder as partial replacement of cement makes concrete very stable and durable but studies has revealed that the strength of cement is not as upto as the conventional cement. We have conducted various test on cement with replacing cement content with glass powder with ration of $0 \%, 5 \%, 10 \%, 15 \%$, $25 \%$ and $30 \%$ and found the results are satisfactory in terms of compressive strength and tensile strength the detailed laboratory test results are discussed in coming chapters of this report. Use of glass powder more than $30 \%$ in cement me leads to loss of strength and durability. Addition of extra bottle glass may leads to problem related to strength and durability. Addition of more pozzolana reduces the strength development in concrete and further alkali are more soluble and leads to surface formation in the form of Na florescence.

\section{LITERATURE REVIEW}

\subsection{SLUMP TEST}

Jangid Jitendra B. and Saoji A.C. [2012] Concluded that the stabilty and workability of concrete reduces with the increase of glass powder percentage.

Khatib J.M et. al [2012] in his study he conlculde that the slump value increase with increase in percentage of glass powder in concrete.

Chikhalikar S.M. and Tande S.N. [2012] In this study shows that $20 \%$ replacement of cement by glass power gives better stability and workability

Vasudevan Gunalaan and Kanapathy pillay Seri Ganis [2013] this study shows use of glass powder to some percentage will be benifical for the workability of concrete.

\subsection{COMPRESSIVE STRENGTH}

Oliveira L.A Pereira de et. al [2010]. In his study he shows that $30 \%$ of upto $75 \mu \mathrm{m}$ waste glass powder can be used as partial replacment in concrete which further helps in increasing the workability of concrete.

Bajad M.N. et. al [2011] his study shows that the strength properties of concrete having glass powder is under attack by sulphate is reduced when cement is replaced with $20 \%$ of glass powder.

Saoji A.C. [2012] concluded that the upto $40 \%$ replacement of cement, compressive strength increase up to $20 \%$ and cement replaced beyond which decreases compressive strength.

Chikhalikar S.M. and Tande S.N. [2012] proved in his study that by using $30 \%$ of glass powder in cement the compreesive strength can be achievd to $100 \%$ in 28 days.

\subsection{FLEXURAL STRENGTH}

Bajad M.N. et. al [2011] He concluded that 20\% replacment of cement with glass powder is beneficial for stability and sulphate attack as well.

Chikhalikar S.M. and.Tande S.N. [2012] Experimentally shows that for the purpose of acheiving flexural strength
$20 \%$ replacment of glass powder with cement is quite sufficent.

Dali J.S. and Tande S.N. [2012] studied show the alternative wetting and drying and high temperatures and showed that $20 \%$ replacement gives higher strength in both the cases.

Jangid Jitendra B. and Saoji A.C. [2012] in his research by using glass powder upto $35 \%$ the flexural strength increase to impressive values.

\subsection{SPLIT TENSILE STRENGTH}

Dali J.S. and Tande S.N. [2012] performed tests on concrete containing mineral admixtures at high temperatures and concluded that $20 \%$ replacement level is optimal when concrete is not subjected to alternative wetting and drying and also when concrete subjected to alternative wetting and drying

Vijayakumar G. et. al [2013] study shows that partial replacement of glass powder increases the tensile strength to some extent as compared to conventional concrete.

Vandhiyan R. et. al [2013] showed study concluded that there is slight improvement in tensile strength of concrete when cement is replaced by glass powder to some percentage.

\section{JUSTIFICATION AND SCOPE}

\subsection{JUSTIFICATION:}

During the period of reaction of tri calcium silicate \& dicalcium silicate with water, calcium silicate hydrate (CSH gel) \& calcium hydroxide are formed.CSH are most important product in the concrete mass, calcium hydroxide is not a desirable product in the concrete mass, it is soluble in water and gets leached out making concrete porous particularly in hydraulic structures. The lack of durability of concrete is on account of presence of calcium hydroxide. The calcium hydroxide also reacts with sulphates present in water to form calcium sulphate which further reacts with C3A cause deterioration of concrete, which is known as sulphate attack.

Glass is amorphous material with high silica content which itself possessing no cementitious properties and in presence of water react with calcium hydroxide liberated in the hydration process to form $\mathrm{CSH}$ gel.

Today world is witnessing the construction of very challenging and aesthetic structures. Concrete being the most important and widely used material due to its high strength and sufficient workability. In the recent, various attempts and research have been made to use ground glass as a replacement in conventional ingredients in concrete productions as a part of green house management. Glass recycling is the process of turning waste glass into usable products. Recycling of waste glass possesses major problems for municipalities everywhere, and this problem can be greatly reduced by re-using waste glasses as cement replacement in concrete.

\subsection{OBJECTIVE:}

The objective of the research is to study or find out the effects of the use of Glass Powder as a partial replacement of cement when mixed in concrete and to know the limit of use of glass powder upto which glass powder can replace cement. In this study, finely powdered waste glasses will be collected from 
different resources and will be used as a partial replacement of cement in concrete and compared it with conventional concrete. This work examines the possibility of using Glass powder as a partial replacement of cement for new concrete. Glass powder will be partially replaced as $5 \%, 10 \%, 15 \%, 20 \%, 25 \% 30 \%$ and will be tested for its compressive, Tensile and flexural strength up to 28 days of age and will be compared with conventional concrete.

$>$ The main objective of this study is to find out the practicality, versatility and feasibility of utilization of recycled glass as a partial replacement ofcement

$>$ To evaluate the recyclability of waste glass powder as a pozzolana as partial replacement of cement in the concrete.

$>$ To Study the influence of waste glass on hardened properties of concrete mixes such as: compressive strength, flexural and splitting resistance.

$>$ Determine the optimum quantity of waste glass powder to be added as a partial replacement of cement.

\subsection{SCOPE:}

Cement manufacturing industry is one of the main reason to produce carbon dioxide emitting sources besides deforestation and burning of fossil fuels. The global warming is highly caused by the emission of green house gases, such as $\mathrm{CO} 2$, to the atmosphere.CO2 contributes about $65 \%$ of global warming. The global cement industry contributes about $7 \%$ of greenhouse gas emission to the earth's atmosphere. In order to address environmental effects associated with cement manufacturing, there is a need to develop alternative binders to make concrete.

$>$ Due to cement replacement by glass powder the cement used in construction will become lesser, thereby effecting the production of cement which in result will affect the production of green house gases positively.

$>$ Many researchers has researched that by replacing of cement with waste glass powder up to $40 \%$, an increase in compressive strength of about $34 \%$ occurs, hence it can be used where high strength concrete is required.

\section{METHODLOGY AND PROCEDURE 4.1 METHODOLOGY:}

After determining the mix design the different constituents of concrete are mixed in their proper proportions, the concrete is then casted in different moulds for the determination of compressive strength, tensile strength, and flexural strength at 7, 28 days. Workability is determined from compaction factor apparatus.

Varying percentage of glass powder such as $5 \%, 10 \%$, $15 \%, 20 \%, 25 \%$ and $30 \%$ are used in concrete casting as a partial replacement of cement and the properties are compared with the control mix. To study the size effect, the different sizes of waste glass powder i-e size less than 75 micron and size between 75 and 150 micron as partial replacement of cement are used in concrete casting and the different properties of concrete are determined and compared along with the conventional concrete.

\subsection{PROCEDURE:}

$>$ The control mix will be M30 design mix according to the design mix IS: 10262(1982).

$>$ For all other mixes the proportions of sand, water and aggregates remain constant.

- Various proportionns of cement are to be replaced by glass powder.

All replacement is to be carried out by weight. Normal tap water will be used for casting and curing.

The test specimen will be cast in cubical steel moulds of standard dimensions

i.e. $50 \times 150 \times 150 \mathrm{~mm}$ for, steel cylindrical moulds of size $150 \times 300$, and steel beams $100 \mathrm{~mm} \times 100 \mathrm{~mm} \times 500 \mathrm{~mm}$ and vibrated on table vibrator for the compaction.

All specimens will be removed from moulds after 24 hours and cured till 28 day.

Tests are carried out for compressive strength, tensile strength and flexural strength and workability tests such as slump and compaction factor test.

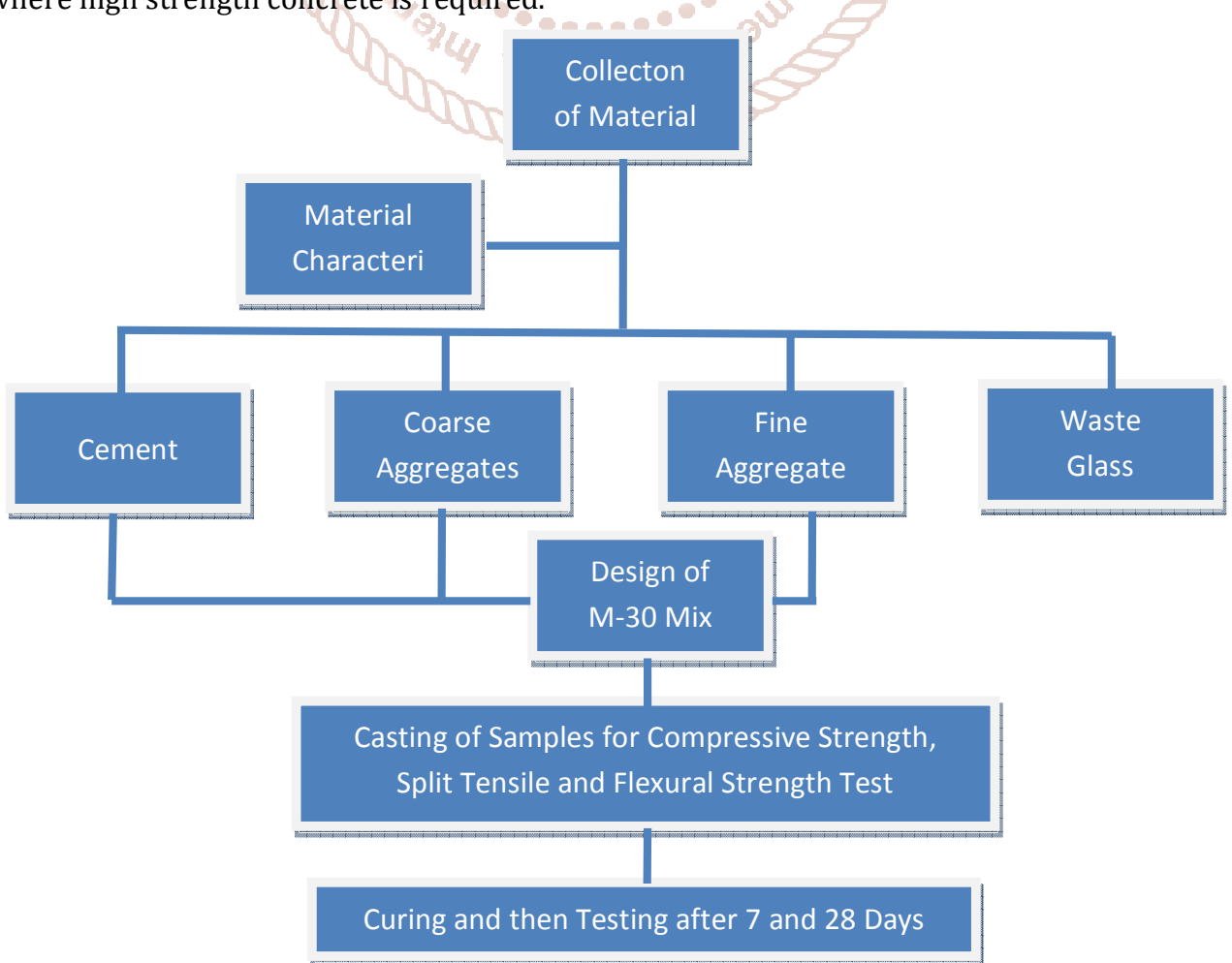

Figure4. 1:- Methodology Showing Mix Design of M-30 and Testing. 


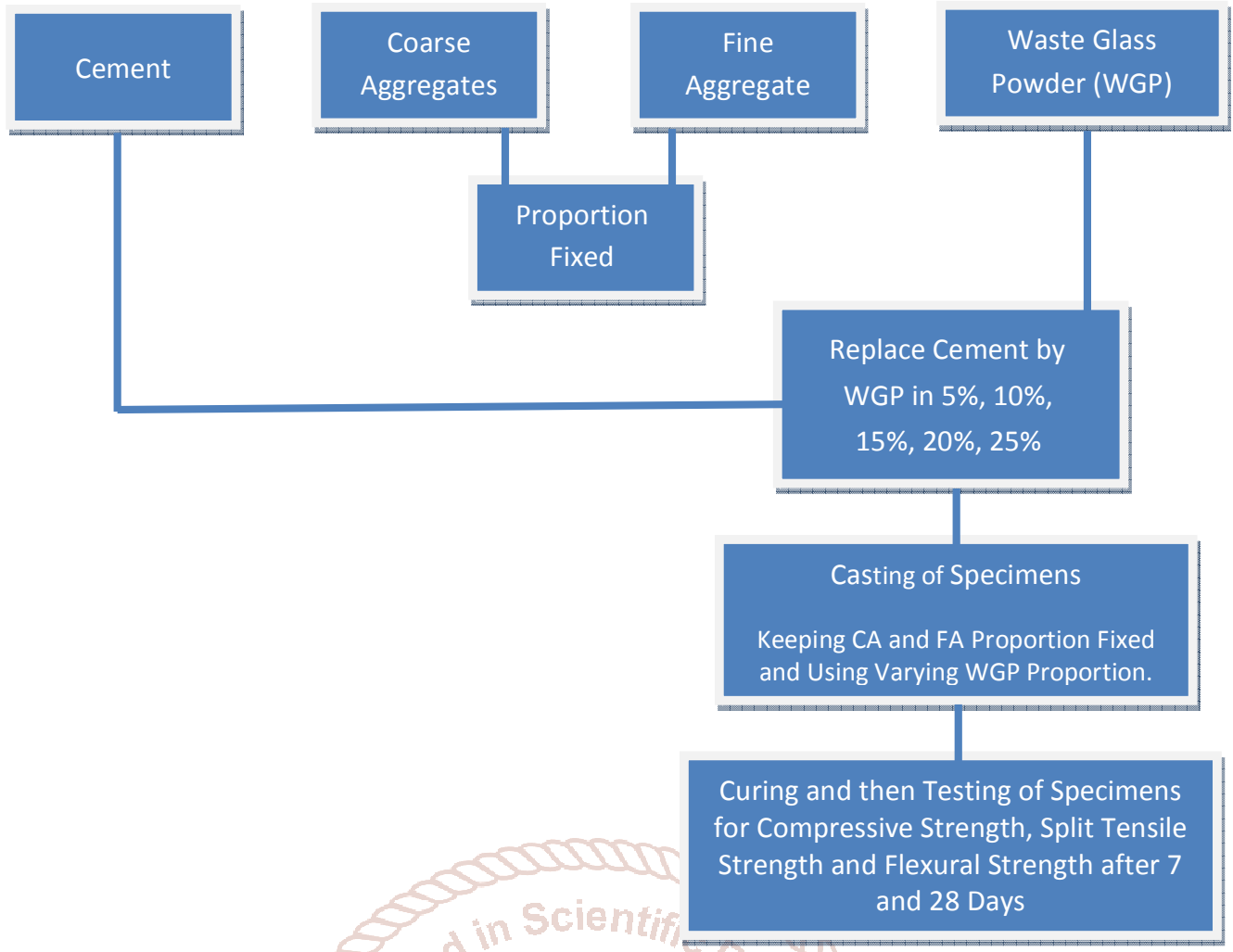

Figure4. 2: Methodology Showing Incorporation of Waste Glass Powder in Concrete Mix

\section{REQUIREMENTS FOR THIS PROJECT \\ 5.1 MATERIALS}

Cement, water and Aggregates: Concrete is prepared by mixing various constituents like cement, aggregates, water etc. which are economically available. Ordinary Portland cement of grade 53 (Khyber) conforming to IS 12269 Will be used throughout the work. The fine aggregate to be used in this investigation is clean river sand collected from wahidpora Ganderbal whose maximum size is $4.75 \mathrm{~mm}$, conforming to IS 3831987 grading zone II. Machine crushed stone angular in shape will be used as coarse aggregate conforming to IS 383 1987,also collected from Ganderbal. The origin of both fine and coarse aggregates being nallah sind. Two sizes of coarse aggregate is used; one $10 \mathrm{~mm}$ and other $20 \mathrm{~mm}$ in the ratio of 70:30.

II. Glass powder: Glass is available locally in shops is been collected and made into glass powder. Glass waste is very hard material. Before adding glass powder in the concrete it has to be powdered to desired size. In this studies glass powder ground in ball/ pulverizer for a period of 30 to 60 minutes resulted in particle sizes less than size $150 \mu \mathrm{m}$ and sieved in $75 \mu \mathrm{m}$.

$>$ Glass is an amorphous (non-crystalline) that in essence, a super cooled liquid and not a solid.

$>$ Glass can be made with excellent homogeneity in a variety of forms and sizes from small fibres to metersizes pieces.

> Primarily glass is made up of sand, soda ash, limestone and other additives (Iron, Chromium, Alumina, Lead and Cobalt).

$>$ Glass has been used as aggregates in construction of road, building and masonry materials.

\section{SOURCE OF GLASS:}

$>$ Sand is filtered through three different size screens having three different sizes.
The finest sand makes the finest glass the largest sand makes the strongest glass.

Sand is melted in crucible to make glass.

\section{SOURCE OF WASTE GLASS:}

Glass food and beverages container

Window repair shops.

Glass decorative items.

Old tube lights, electric bulbs.

Glass polishing and glass window and door manufacturing shop.

\section{CASTING OF SPECIMEN:}

$>$ Seven types of mix will considered; of which One control mixture S-1 (without glass powder) will designed according to Indian Standard Specification IS: 10262(1999)

$>$ The other six concrete mixes will be made by replacing the cement with 5\%,10\%,15\%, 20\%,25\%, $30 \%$ of glass powder weight.

\subsection{APPARATUS AND INSTRUMENTS:}

Different instruments and apparatus are required for this project work .cubical moulds of size $150 \times 150 \times 150 \mathrm{~mm}$ made of steel are used for the determination of compressive strength .Cylindrical steel moulds of diameter $150 \mathrm{~mm}$ and height $300 \mathrm{~mm}$ are required for the determination of split tensile strength. Steel beams of size $100 \mathrm{~mm} \times 100 \mathrm{~mm} x$ $500 \mathrm{~mm}$ are required for the determination of flexural strength.

Various instruments such as UTM is used for strength determination .Vicat apparatus is used for determination of consistency of cement, initial and final setting times of cement compaction factor apparatus is used for the determination of compaction factor. A pycnometer is used 
for the determination of specific gravity of sand and glass powder.A wire basket method is used for the determination of specific gravity of coarse aggregate. A set of sieves is used for determining the zoning of sand. A table vibrator is also needed for the compaction of concrete moulds.

\section{MATERIAL TESTS}

\subsection{CEMENT TESTS (IS: 4031)}

Following tests were conducted on the cement used (OPC 53

Grade Khyber Cement)

$>$ Physical test

$>$ Fineness test

$>$ Specific gravity test

$>$ Standard consistency

$>$ Initial setting time

$>$ Final setting time

$>$ Compressive strength of cement

\subsubsection{PHYSICAL TEST:}

$>$ Open the bag and take a good look at the cement. There should not be any visible lumps in cement. The colour of cement should be greenish grey.

$>$ Thrust your hand into the cement bag. It must be giving you a cool feeling. There should not be any lump inside.

$>$ Take a pinch of cement and feel-between the two fingers. It should give a smooth and not a gritty feeling.

$>$ Take a handful of cement and throw it on a bucket full of water, the particle should float for some time before they sink.

$>$ Take about 100 grams of cement and a small quantity of water and make a stiff paste. From the stiff paste, pat a cake with sharp edges. Put it on a glass plate and slowly take it under water in a bucket. See that the shape of the cake is not disturbed while taking it down to the bottom of the bucket. After 24 hours the cake should retain its original shape and at the same time it should also set and attain some strength.

\subsubsection{FINENESS TEST:}

Fineness of cement is property of cement that indicate particle size of cement and specific surface area and indirectly effect heat of hydration. If fineness is more then heat of hydration should be more.

Table 6.1 Determination of fineness of cement

\begin{tabular}{|c|c|c|c|c|c|c|}
\hline S.NO & $\begin{array}{c}\text { Wt of } \\
\text { cement (gm) }\end{array}$ & $\begin{array}{c}\text { Wt of Residue 90 } \\
\text { micron sieve }(\mathrm{gm})\end{array}$ & $\begin{array}{c}\text { Percentage } \\
\text { residue. }\end{array}$ & $\begin{array}{c}\text { Average } \\
\text { value \% }\end{array}$ & $\begin{array}{c}\text { Permissible } \\
\text { values as IS 4031 }\end{array}$ & Remarks \\
\hline 1 & 100 & 7 & 7 & & & \\
\end{tabular}

6.2 GRADIATION OF SAND (AS PER IS: 383-1970)

Weight of sample taken is $1000 \mathrm{~g}$

Table 6.2 Sieve analysis of sand

\begin{tabular}{|c|c|c|c|c|}
\hline Size sieve & Weight retained(g) & \%weight retained & Cumulative \% wt. retained & \% finer \\
\hline $4.75 \mathrm{~mm}$ & 2 & .2 & .2 & 99.8 \\
\hline $2.36 \mathrm{~mm}$ & 7.333 & 0.733 & .933 & 99.067 \\
\hline $1.18 \mathrm{~mm}$ & 53.666 & 5.36 & 6.293 & 93.70 \\
\hline $600 \mu$ & 498.33 & 49.8 & 56.09 & 43.91 \\
\hline $300 \mu$ & 398.666 & 39.86 & 95.95 & 4.05 \\
\hline $150 \mu$ & 33.666 & 3.36 & 99.31 & 0.69 \\
\hline
\end{tabular}

As the percentage passing $600 \mu$ sieve is between $35 \& 59$, the sand falls in zone II of gradation.

\subsection{GRADATION CURVE:}

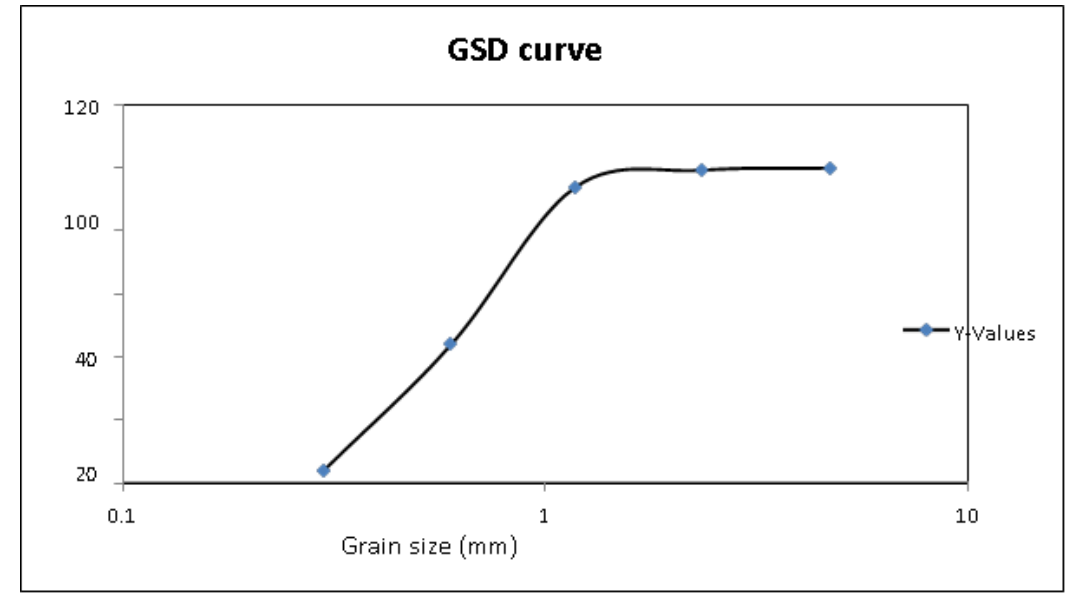

Figure 6.1 Grain size distribution of sand

From the gradiation curve we find that D10 $=0.33$ D30 $=0.48$ D60 $=0.72$

$\mathrm{Cu}=\mathrm{D} 60 / \mathrm{D} 10=0.72 / 0.33=2.18$

$\mathrm{Cc}=\mathrm{D} 302 /(\mathrm{D} 10 \times \mathrm{D} 60)=2.02$

Thus the sand is poorly graded sand. 


\subsection{FINENESS MODULUS:}

Fineness modulus is an empirical factor obtained by adding the cumulative percentages of aggregates retained on each of the standard sieves ranging from $80 \mathrm{~mm}$ to 150 micron and dividing this by an arbitary number 100 .

Hence F.M $=(0.2+.93+6.293+56.09+95.95+99.31) / 100$ $=2.587$

As fineness modulus is between 2.2 and 2.6 the sand is fine sand.

\subsection{SPECIFIC GRAVITY OF SAND:}

The test is conducted by pycnometer method. The observations are taken at $110 \mathrm{c}$ are as:

Weight of empty pycnometer $\mathrm{W} 1=0.692 \mathrm{~kg}$.

Weight of pycnometer + dry sample $\mathrm{W} 2=0.892 \mathrm{~kg}$

Weight of pycnometer +sample + water W3 =1.668 kg. Weight of pycnometer + water $\mathrm{W} 4=1.544 \mathrm{~kg}$

Specific gravity is given by the following formula:

$\mathrm{G}=\mathrm{W} 2-\mathrm{W} 1 / \mathrm{W} 2-\mathrm{W} 1)-(\mathrm{W} 3-\mathrm{W} 4)$

$\mathrm{G}=0.2 / 0.076$

$\mathrm{G}=2.63$

\subsection{SPECIFIC GRAVITY OF COARSE AGGREGATE:}

The test is conducted by wire basket method at $110 \mathrm{c}$ and the readings are presented as :

Weight of oven dry sample $\mathrm{W} 1=500 \mathrm{gm}$

Weight of empty wire basket in water $W 2=891 \mathrm{gm}$

Weight of basket and sample in water $\mathrm{W} 3=578.5 \mathrm{gm}$

Specific gravity G=W1/(W1-(W2-W3)

$\mathrm{G}=500 / 500-(891-578.5)$

$\mathrm{G}=2.67$

\subsection{STANDARD CONSISTENCY TEST FOR CEMENT:}

Standard consistency test of a cement is defined as the water content at which the paste permit a vicat plunger having $10 \mathrm{~mm}$ dia and $500 \mathrm{~mm}$ length to penetrate to a depth of 33$35 \mathrm{~mm}$ from the top of the mould. The test is useful for finding out initial setting time, final setting time, soundness and strength of cement. The test is conducted using vicat apparatus. The observations obtained during the test are as: Weight of cement taken for each trial is 400 gram

Table 6.3 Standard consistency of cement \begin{tabular}{|l|l|l|}
\hline Trial no & Water content (\%) & Penetration \\
\hline 1 &
\end{tabular}

\begin{tabular}{|c|c|c|}
\hline 1 & 25 & 15 \\
\hline 2 & 27 & 20 \\
\hline 3 & 29 & 32 \\
\hline 4 & 30 & 34 \\
\hline 5 & 31 & 35.5 \\
\hline
\end{tabular}

The standard consistency of the cement is obtained as $30 \%$

\subsection{INITIAL SETTING TIME OF CEMENT:}

Initial setting time of cement is regarded as the time elapsed between the movement that the water is added to the cement , to the time that the paste starts losing its plasticity. In vicat apparatus, it is measured as the period elapsed between the time when water is added to the cement and the time at which the needle penetrates the test block to a depth equal to 33-35mm.
From the top at a water content of 0.85 times the standard consistency. The observations obtained at a temperature of 80c are as:

Weight of cement $=400$ gram

Weight of water $=0.85 \mathrm{P}$

$=0.85 \times 30 / 100 \times 400$

$=102 \mathrm{gm}$.

Time at which water is added to the cement 2:05 pm

Time at which needle penetrates to a depth of $33-35 \mathrm{~mm}$, 5:45pm Initial setting time is obtained as $3 \mathrm{hr} 40 \mathrm{~min}$.

\subsection{FINAL SETTING TIME OF CEMENT:}

The final setting time is the time elapsed between the movement the water is added to the cement, and the time when the paste has completely lost its plasticity and has attained sufficient firmness to resist certain definite pressure. In vicats apparatus cement is considered finally set, when upon lowering the attachment gently cover the surface of test block, the centre needle makes an impression,while the circular cutting edge of the attachment fails to do so, that is the needle does not pierce more than $0.5 \mathrm{~mm}$.

The observations obtained are as:

Time at which water is added to the cement $=2: 05 \mathrm{pm}$

Time at which circular edge fail to make impression=7:25pm. Final setting time is obtained as $5 \mathrm{hr} 20 \mathrm{~min}$.

\subsection{TRIAL MIX DESIGN:}

A trial mix design has been obtained for an assumed compaction factor of 0.80 as per IS: 10262 (1982).The trial mix is obtained as 1:1.4:2.8 for a water cement ratio of 0.45 .

\subsection{COMPACTION FACTOR:}

Compaction factor is defined as the ratio of density achieved when concrete is allowed to fall through a standard height and the density of same concrete fully compacted.

The observations during the test are:

Weight of empty cylinder w $1=18.7 \mathrm{~kg}$

Weight of cylinder + partially compacted concrete $\mathrm{W} 2=29.5 \mathrm{~kg}$

Weight of cylinder + fully compacted concrete $W 3=31.3 \mathrm{~kg}$

$\mathrm{CF}=(\mathrm{W} 2-\mathrm{W} 1) /(\mathrm{W} 3-\mathrm{W} 1) \mathrm{CF}=(29.5-18.7) /(31.3-18.7)$ $\mathrm{CF}=0.85$

\subsection{DESIGN MIX:IS:10262-1982:}

$>$ Characteristic strength required at 28 days $=30 \mathrm{Mpa}$.

$>$ Target mean strength $=\mathrm{fck}+1.65 \mathrm{~S}$

$=30+1.65 \times 4$

$=36.6 \mathrm{Mpa}$

$>$ For 53 grade cement and target strength of $36.6 \mathrm{Mpa}$, the $\mathrm{w} / \mathrm{c}$ is obtained as 0.47 but from the durability condition maximum $\mathrm{w} / \mathrm{c}$ for M30 is 0.45 .hence adopt $\mathrm{w} / \mathrm{c}$ ratio of 0.45

$>$ For 20mm maximum size aggregate, sand conforming to grading zone II,water cement ratio of 0.6 and compaction factor of 0.8 water content per cubic metre of concrete $=186 \mathrm{kgand}$ sand content as percentage of total aggregate by absolute volume $=35 \%$. 
$>$ Adjustments to water and sand For compaction factor of $0.85(+0.05)$ water content is increased by $1.5 \%$ and no adjustment to sand.

- For w/c ratio of $0.45(-0.15)$ sand is reduced by $3 \%$ and no adjustment is made to water content.

- $\quad$ Final water content $=188.8 \mathrm{~kg} / \mathrm{m} 3$ and sand content of $32 \%$ of total aggregate.

$>$ Cement content $=188.8 / 0.45=419.5 \mathrm{~kg}$

$>$ Entrapped air for maximum size of aggregate $=2 \%$

$>$ Aggregate content is obtained by using the formula:

$$
\begin{gathered}
V=\left(W+\frac{C}{S_{e}}+\frac{1}{P}\left(\frac{f^{a}}{S_{f a}}\right)\right) \times \frac{1}{1000} \\
C=\frac{{ }^{1-P}}{P} \times f{ }_{a} \vee \frac{S_{c a}}{S_{f a}}
\end{gathered}
$$

$\mathrm{V}=$ absolute volume of fresh concrete.

$\mathrm{W}=$ mass of water $/ \mathrm{m} 3$ of concrete.

Sc =specific gravity of cement.

$\mathrm{P} \quad=$ Ratio of FA to total aggregate by absolute volume.

$\mathrm{Fa}, \mathrm{ca}=$ total mass of FA and $\mathrm{CA}(\mathrm{KG})$ per metre cube of concrete.

Sfa, Sca = Specific gravities of saturated , surface dry fine $\mathrm{FA}=554 \mathrm{~kg}$. aggregate and coarse aggregate respectively.

$\mathrm{CA}=1195 \mathrm{~kg}$.

Design mix is obtained as 419.5: $554: 1195=1: 1.3: 2.8$

6.13 PHYSICAL PROPERTIES OF GLASS POWDER

Specific gravity $=2.6$

Finess passing $=100$

Colour $\quad=$ grayish white

6.14 CHEMICAL PROPERTIES OF GLASS POWDER $\mathrm{PH}=10.17$

Table 6.4 Chemical composition of Glass powder

\begin{tabular}{|c|c|}
\hline Component & $\%$ by mass \\
\hline $\mathrm{SiO}_{2}$ & 67.330 \\
\hline $\mathrm{Al}_{2} \mathrm{O}_{3}$ & 2.620 \\
\hline $\mathrm{Fe}_{2} \mathrm{O}_{3}$ & 1.420 \\
\hline $\mathrm{TiO}_{2}$ & 0.157 \\
\hline $\mathrm{CaO}$ & 12.450 \\
\hline $\mathrm{MgO}$ & 2.738 \\
\hline $\mathrm{Na}_{2} \mathrm{O}$ & 12.050 \\
\hline $\mathrm{K}_{2} \mathrm{O}$ & 0.638 \\
\hline $\mathrm{ZrO}$ & 0.019 \\
\hline $\mathrm{ZnO}$ & 0.008 \\
\hline $\mathrm{SrO}$ & 0.016 \\
\hline $\mathrm{NiO}$ & 0.014 \\
\hline
\end{tabular}

6.15 RESULTS OBTAINED VIA MATERIAL TESTING :

$>\quad$ Sand conforms to zone II

$>$ Sand is poorly graded.

$>\quad$ Fineness modulus of sand is 2.58 , hence the sand is fine sand.

$>\quad$ Specific gravity of sand is 2.63

$>\quad$ Specific gravity of coarse aggregate is 2.67

$>$ Standard consistency of cement is $30 \%$

$>\quad$ Initial setting time of cement is $3 \mathrm{hr} 40 \mathrm{~min}$

$>\quad$ Final setting time of cement is $5 \mathrm{hr} 20 \mathrm{~min}$

$>\quad$ Compaction factor of concrete is obtained as 0.85

$>\quad$ Mix design as 1: 1.3: 2.8 with $\mathrm{w} / \mathrm{c}$ ratio 0.45 .

\section{EXPERIMENTAL WORK}

\subsection{PREPARATION OF MATERIALS}

All the materials shall be brought to room temperature, preferably $700 \mathrm{C}$ before start the work. The cement samples at the laboratory shall be carefully mixed dry either by hands or by a mixer in such a manner as to ensure the maximum possible blending and uniformity in the material. The cement then be stored in a dry place, preferably in air-tight metal containers. Samples of aggregates for each batch of concrete shall be of the desired grading and shall be in an air-dried condition. In general, the aggregate shall be separated into fine and coarse portion and recombined for each concrete batch in such a way as to produce the desired grading. IS sieve 480 shall be normally used for separating the fine and coarse aggregates, but where special grading are being investigated, both fine and coarse aggregate shall be separated into different sizes.

\subsubsection{PROPORTIONING}

The proportions of the materials, including water, in concrete mixes used for determining the suitability of the materials available, shall be similar in all respects to those to be employed in the work. Where the proportions of the ingredients of the concrete as used on the site are to be specified by volume and shall be calculated from the proportions by weight used in the test cubes and the unit weights of the materials.

\subsubsection{WEIGHING}

Weigh batching is the correct method of measuring the materials. For important concrete, invariably weigh batching should be adopted. Use of weight system in batching, facilitates accuracy, flexibility and simplicity.

\subsubsection{MIXING CONCRETE}

Proper mixing of the materials is essential for the production of uniform and good concrete. The mixing should be done to ensure that the mass become homogeneous, uniform in colour and consistency. There are two different methods for mixing concrete hand mixing and machine mixing.

\subsubsection{COMPACTION OF TEST SPECIMENS: (AS PER IS: 516-1959)}

Compaction of concrete is the process adopted for expelling the entrapped air from the concrete. In the process of mixing, transporting and placing of concrete air is entrapped in the concrete. The lower the workability, the higher is the amount of air entrapped. In other words, stiff concrete mix has high percentage of entrapped air and, therefore, would need higher compacting efforts than high workable mixes. Therefore, it is imperative that $100 \%$ compacting of concrete is one of the most important aim to be kept in mind in good concrete making practices.

\subsubsection{COMPACTION BY VIBRATION}

When compacting by vibration, each layer shall be vibrated by means of an electric vibrator or by means of a suitable vibrating table until the specified condition is attained.

\subsubsection{PLACING MOULDS ON THE VIBRATING TABLE}

This is the special case of formwork vibrator, where the vibrator is clamped to the table or table is mounted on springs which are vibrated transferring the vibration to the table. They are commonly used for vibrating concrete cubes. Any specimen kept on the table gets vibrated. 


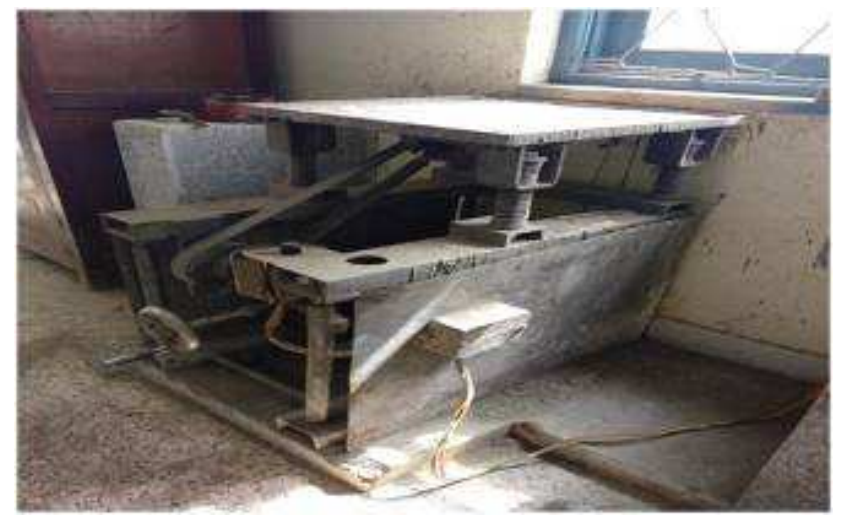

Figure 7.1. Vibrating table

\subsubsection{CURING OF TEST SPECIMENS: (AS PER IS: 516- 1959)}

The test specimens shall be stored on the site at a place under damp matting, sacks or other similar material for 24 hours $+1 / 2$ hour from the time of adding the water to the other ingredients. The temperature of the place of storage shall be within the range of 0 to $0 \mathrm{C}$. After the period of 24 hours, they shall be marked for later classification, removed from the moulds and, unless required for testing within 4 hours, stored in clean water at a temperature of 40 to $00 \mathrm{C}$ until they are transported to the testing laboratory. They shall be sent to the testing laboratory well packed in damp sand, damp sacks, or other suitable material so as to arrive there in a damp condition not less than 4 hours before the time of test. $n$ arrival at the testing laboratory, the specimens shall be stored in water at a temperature of $700 \mathrm{C}$ until the time of test.

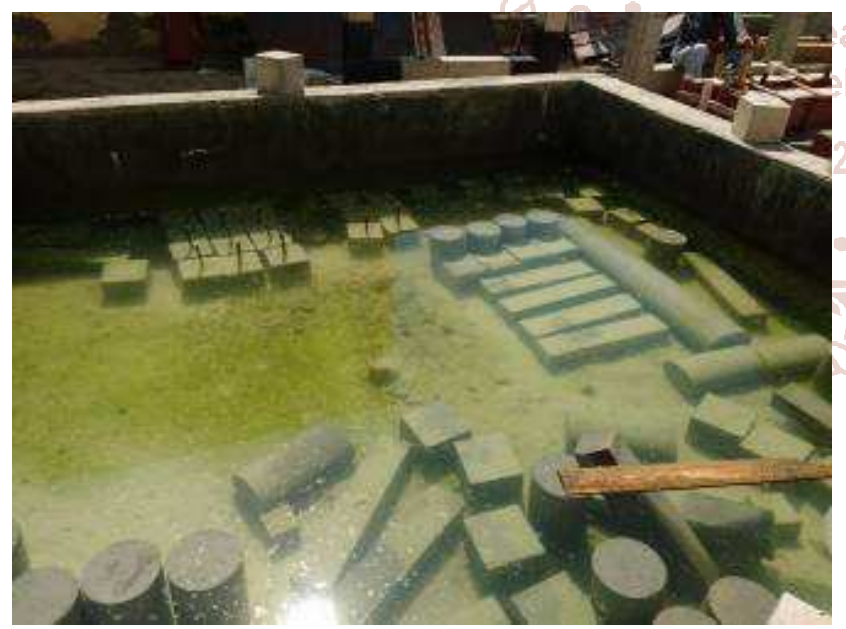

Fig 7.2.Curing of test specimens.

The experimental work was carried out in Balaji scientific laboratory, NIT Faridabad. In this study, total of seven groups of concrete mixes were prepared in laboratory. First group was normal cement concrete mix. Second, third, fourth , fifth, sixth , and seventh group was cement replacement by fine glass powder (GLP) particle size less than 75 micron with replacement from 5\%,10\%, 15\%,20\%,25\% and $30 \%$ respectively.

\subsection{COMPRESSIVE STRENGTH TEST}

Seven different mixes (Mix1, Mix2, Mix3, Mix4, Mix 5,Mix 6, \& Mix 7) were prepared using cement replaced by glass powder at varying percentage of $0,5,10,15,20,25$ and 30. Fourty two number standard specimens of dimensions $150 \times 150$ $\times 150 \mathrm{~mm}$ were cast according to the mix proportion and cured in water at room temperature in the laboratory for 7 and 28 days. At the end of each curing period, three specimens for each mixes were tested for compressive strength and the average strength was recorded. The size of the specimen is as per the IS code 10086 - 1982. The compressive strength test on both conventional and glass added concrete was performed on standard compression testing machine of $3000 \mathrm{kN}$ capacity, as per IS: 516-1959.

The load shall be applied slowly without shock and increased continuously at a rate of approximately $140 \mathrm{~kg} / \mathrm{sq} . \mathrm{cm} / \mathrm{min}$ until the resistance of the specimen to the increased load breaks down and no greater load can be sustained.

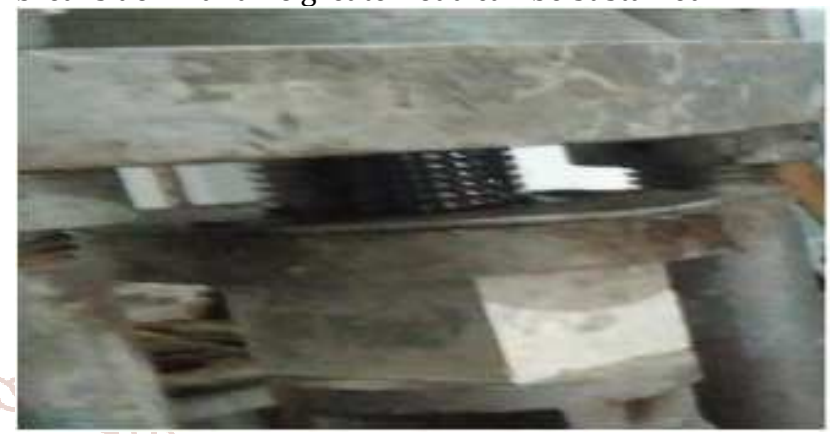

Fig 7.3: compression test

Compressive strength is calculate using the following formula Compressive strength $=\mathrm{Wf} / \mathrm{Ap}$

Where, Wf = Maximum applied load just before load, Ap = Plan area of cube mould.

\subsection{SPLIT TENSILE STRENGTH OF CONCRETE}

Seven different mixes (Mix1, Mix2, Mix3, Mix4, Mix5, Mix6, Mix7) were prepared using cement replaced by glass powder at varying percentage of $0,5,10,15,20,25$ and 30 . Forty two number standard specimens of dimensions $300 \mathrm{~mm}$ length and $150 \mathrm{~mm}$ diameter were cast according to the mix proportion and cured in water at room temperature in the laboratory for 7 and 28 days. The test is carried out by placing a cylindrical specimen horizontally between the loading surfaces of a compression testing machine and the load is applied until failure of cylinder along the vertical diameter.

Split tensile strength, $(\mathrm{T})=\mathrm{P} / \pi \mathrm{DL}$

Where, $\mathrm{P}=$ compressive load on cylinder

$\mathrm{L}=$ length of cylinder

$\mathrm{D}=$ diameter of cylinder

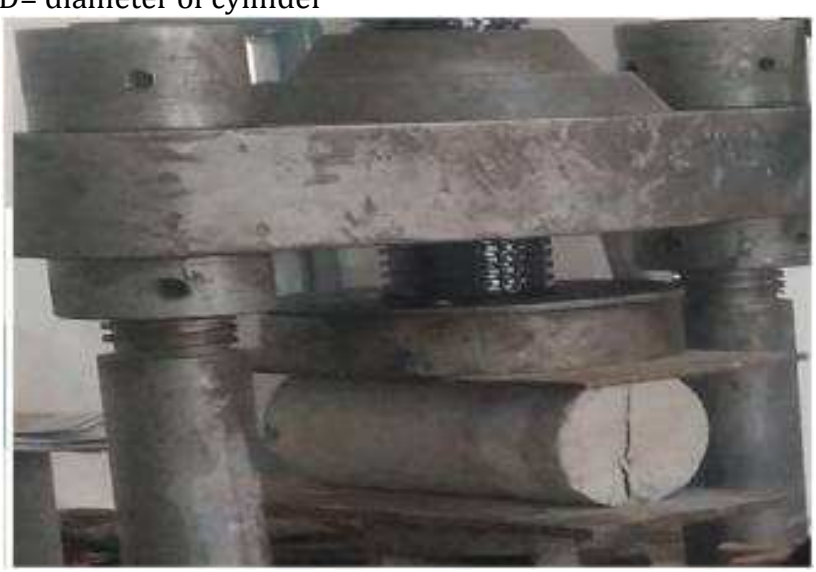

Fig7.4 split tensile test 


\subsection{FLEXURAL STRENGTH OF CONCRETE:}

Seven different mixes (Mix1, Mix2, Mix3, Mix4, MIX5, Mix6, Mix7) were prepared using cement replaced by glass powder at varying percentage of $0,5,10,15,20,25$ and 30 . Forty two number standard specimens of $500 \times 100 \times 100 \mathrm{~mm}$ were cast according to the mix proportion and cured in water at room temperature in the laboratory for 7 and 28 days. The test is carried by placing specimen on hydraulic testing machine after marking the specimen as shown in fig 5 Flexural strength,

$\mathrm{fb}=\mathrm{P} \times \mathrm{L} / \mathrm{bd} 2$

Where, $\mathrm{P}=\mathrm{load}$ at failure
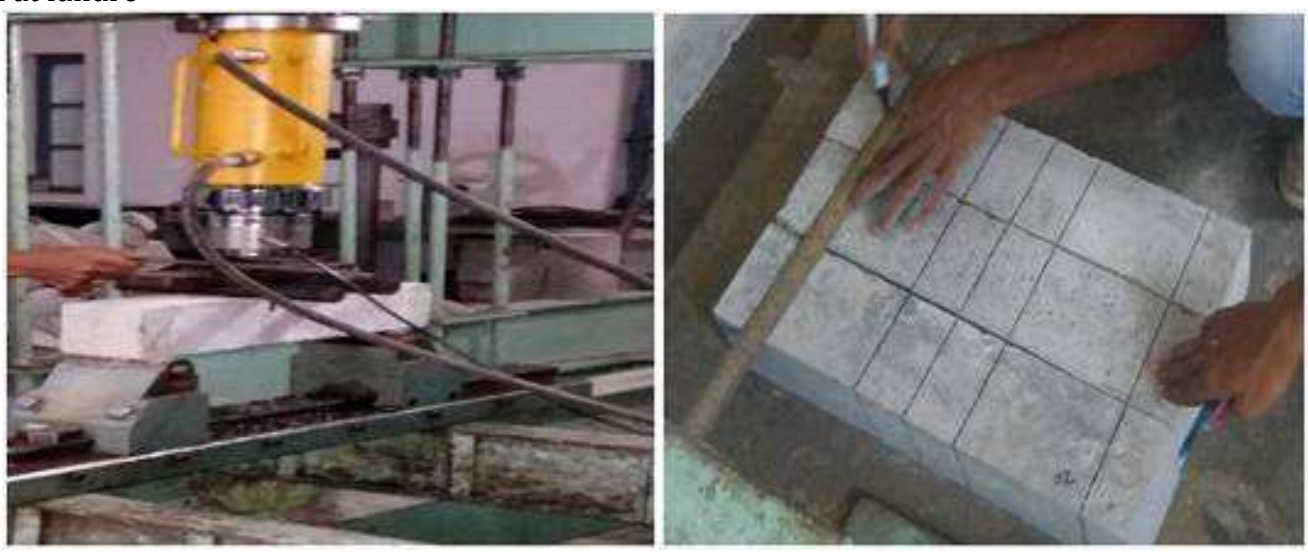

$\mathrm{L}=$ length of specimen, $\mathrm{b}$ \& $\mathrm{d}$ are width and depth respectively.

Fig 7.5: schematic representation of a) flexural strength test b) marking of specimen

8. RESULTS AND DISCUSSIONS

\subsection{COMPRESSIVE STRENGTH OF M30 CONCRETE ON 7TH DAY}

Table 8.1 7- Day Compressive Strength

\begin{tabular}{|c|c|c|c|c|c|c|c|}
\hline \multirow{2}{*}{ S. No } & \multirow{2}{*}{\multicolumn{2}{|c|}{ Percentage of glass powder }} & \multicolumn{3}{|c|}{ Compressive strength $\mathrm{N} / \mathrm{mm}^{2}$} & \multirow{2}{*}{\multicolumn{2}{|c|}{ Average compressive strength $\mathrm{N} / \mathrm{mm}^{2}$}} \\
\hline & & & Sample 1 & Sample 2 & Sample 3 & & \\
\hline 1 & $0 \%$ & 2 & 21.90 & 21.98 & 22.06 & $\mathrm{c}$ & 21.98 \\
\hline 2 & $5 \%$ & 8 & 19.03 & 19.21 & 18.99 & $?$ & 19.07 \\
\hline 3 & $10 \%$ & 8 & 18.33 & 18.61 & 18.47 & as 8 & 18.47 \\
\hline 4 & $15 \%$ & 0 & 17.77 & 17.90 & 18.15 & 3 & 17.94 \\
\hline 5 & $20 \%$ & $\alpha=$ & 19.20 & 19.28 & 19.36 & 58 & 19.28 \\
\hline 6 & $25 \%$ & $\mathrm{~B}$ & 19.01 & De 19.03 & en18.66 & 8 & 18.91 \\
\hline 7 & $30 \%$ & 8 & 16.57 & 16.61 & 16.74 & 28 & 16.64 \\
\hline
\end{tabular}

\subsection{COMPRESSIVE STRENGTH OF M30 CONCRETE ON 28th DAY}

Table 8.2 28 Day compressive strength

\begin{tabular}{|c|c|c|c|c|c|}
\hline \multirow{2}{*}{ S. No } & \multirow{2}{*}{ Percentage of glass powder } & \multicolumn{3}{|c|}{ Compressive strength $\mathrm{N} / \mathrm{mm}^{2}$} & \multirow{2}{*}{ Average compressive strength $\mathrm{N} / \mathrm{mm}^{2}$} \\
\hline & & Sample 1 & Sample 2 & Sample 3 & \\
\hline 1 & $0 \%$ & 31.11 & 31.05 & 31.09 & 31.08 \\
\hline 2 & $5 \%$ & 32.19 & 32.78 & 31.73 & 32.23 \\
\hline 3 & $10 \%$ & 33.00 & 33.11 & 33.08 & 33.06 \\
\hline 4 & $15 \%$ & 34.01 & 34.66 & 34.91 & 34.52 \\
\hline 5 & $20 \%$ & 35.76 & 36.02 & 36.41 & 36.06 \\
\hline 6 & $25 \%$ & 33.01 & 33.11 & 33.08 & 33.06 \\
\hline 7 & $30 \%$ & 31.53 & 31.21 & 30.07 & 30.96 \\
\hline
\end{tabular}

8.3 COMPARISON OF COMPRESSIVE STRENGTH OF M3O CONCRETE WITH DIFF PERCENTAGES OF GLASS POWDER ON 7TH AND 28TH DAY.

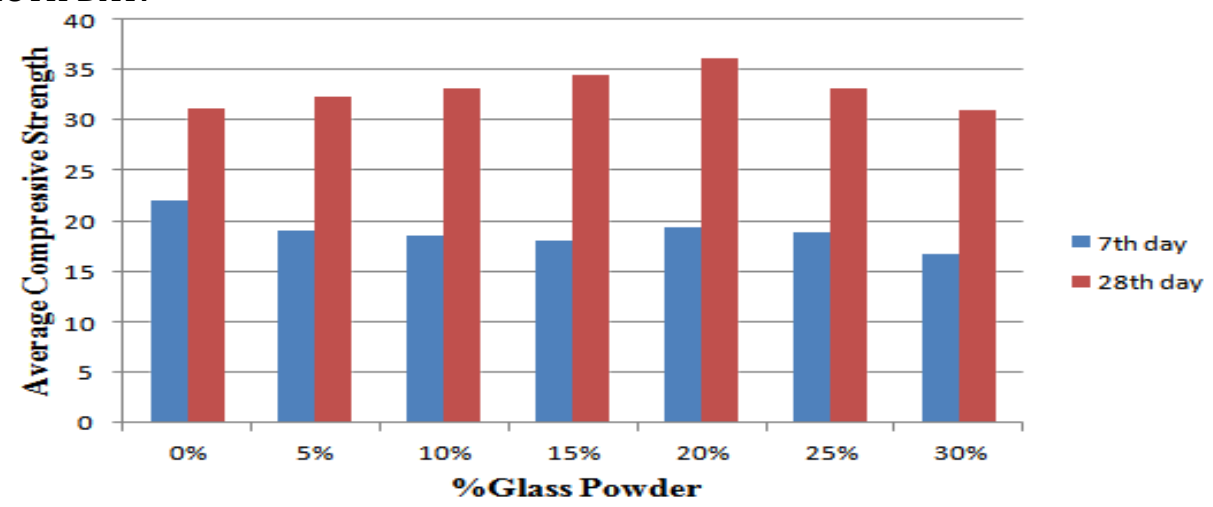

Fig. 8.1 comparison of compressive strength at 7 and 28 Days curing periods 
International Journal of Trend in Scientific Research and Development (IJTSRD) @ www.ijtsrd.com eISSN: 2456-6470

$>$ On addition of GLP initial rate of gain of strength is low but at 28th day strength more than the design strength.

$>$ Addition of GLP increases the strength of concrete.

$>$ At the level of $20 \%$ replacement of cement by glass powder, strength is higher as compare to that of normal concrete and other percentage of replacement of cement on 28th day.

$>$ The compressive strength of glass powder concrete shows an increment of about $18 \%$ at the age of 28 th days at optimum point i-e $20 \%$ replacement of cement by waste glass powder.

\subsection{COMPARISON OF COMPRESSIVE STRENGTH OF M3O CONCRETE WITH DIFF PERCENTAGES OF GLASS POWDER ON 7TH AND 28TH DAY.}

8.5 FLEXURAL STRENGTH OF M30 CONCRETE ON 7TH DAY.

Table 8.3 flexural strength of M30 Concrete on 7Day

\begin{tabular}{|c|c|c|c|c|c|}
\hline \multirow{2}{*}{ S. no } & Percentage of glass powder & \multicolumn{2}{|c|}{ Compressive strength $\mathbf{~} / \mathbf{m m}^{2}$} & \multirow{2}{*}{ Average compressive strength N/mm ${ }^{2}$} \\
\cline { 3 - 5 } & & Sample 1 & Sample 2 & Sample 3 & \\
\hline 1 & $0 \%$ & 31.11 & 31.05 & 31.09 & 31.08 \\
\hline 3 & $5 \%$ & 32.19 & 32.78 & 31.73 & 32.23 \\
\hline 4 & $10 \%$ & 33.00 & 33.11 & 33.08 & 33.06 \\
\hline 5 & $15 \%$ & 34.01 & 34.66 & 34.91 & 34.52 \\
\hline 6 & $20 \%$ & 35.76 & 36.02 & 36.41 & 36.06 \\
\hline 7 & $25 \%$ & 33.01 & 33.11 & 33.08 & 33.06 \\
\hline
\end{tabular}

\subsection{FLEXURAL STRENGTH OF M30 CONCRETE ON 28TH DAY}

Table 8.4 Flexural strength of M30 concrete on 28 Days

\begin{tabular}{|c|c|c|c|c|c|}
\hline \multirow{2}{*}{ S no } & \multirow{2}{*}{ Percentage of glass powder } & \multicolumn{3}{|c|}{ Compressive strength $\mathrm{N} / \mathrm{mm}^{2}$} & \multirow{2}{*}{ Average compressive strength $\mathrm{N} / \mathrm{mm}^{2}$} \\
\hline & & Sample 1 & Sample 2 & Sample 3 & \\
\hline 1 & $0 \%$ & 31.11 & 31.05 & 31.09 & 31.08 \\
\hline 2 & $5 \%$ & 32.19 & 32.78 & 31.73 & \pm 8 \\
\hline 3 & $10 \%$ & 33.00 & 33.11 & 33.08 & 28 \\
\hline 4 & $15 \%$ & 34.01 & $3134.666=$ & 4734.91 & 8 \\
\hline 5 & $20 \%$ & 35.76 & 36.02 & 36.41 & 36.06 \\
\hline 6 & $25 \%$ & 33.01 & 33.11 & 33.08 & 33.06 \\
\hline 7 & $30 \%$ & 31.53 & 31.21 & 30.07 & 30.96 \\
\hline
\end{tabular}

8.7 COMPARISON OF FLEXURAL STRENGTH OF M3O CONCRETE WITH DIFF PERCENTAGES OF GLASS POWDER ON 7TH AND 28TH DAY

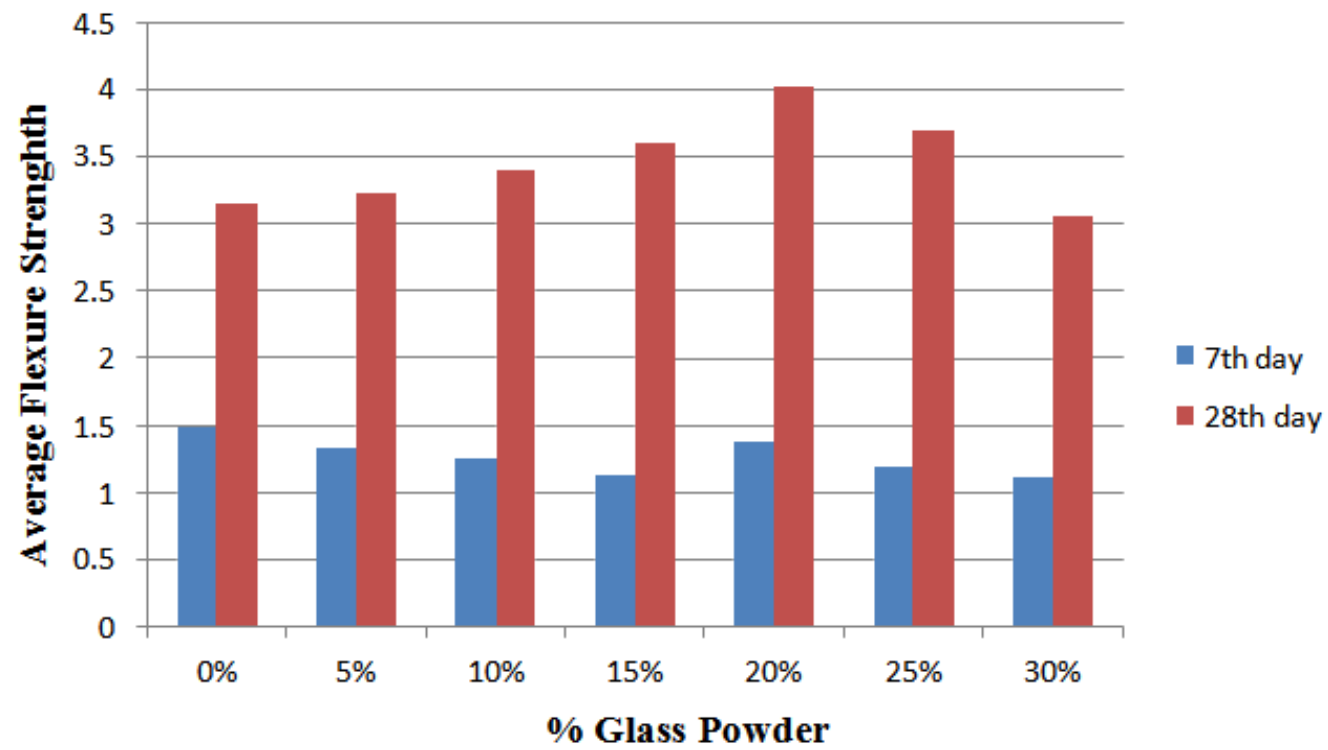

Fig. 8.2 Comparison of Flexural strength of M30 concrete with diff percentages of glass powder on 7th and 28th day 
International Journal of Trend in Scientific Research and Development (IJTSRD) @ www.ijtsrd.com eISSN: 2456-6470

8.8 SPLIT TENSILE STRENGTH ON 7TH DAY.

Table 8.5 Split tensile strength of M30 concrete on 7th day

\begin{tabular}{|c|c|c|c|c|c|}
\hline \multirow{2}{*}{ S. no } & \multirow{2}{*}{ Percentage of glass powder } & \multicolumn{2}{|c|}{ Split tensile strength $\mathbf{~} \mathbf{m m}^{2}$} & \multirow{2}{*}{ Average split tensile strength N/mm ${ }^{2}$} \\
\cline { 3 - 5 } & $0 \%$ & Sample 1 & Sample 2 & Sample 3 & \\
\hline 1 & $5 \%$ & 1.45 & 1.28 & 1.66 & 1.46 \\
\hline 2 & $10 \%$ & 1.66 & 1.07 & 1.30 & 1.34 \\
\hline 3 & $15 \%$ & 1.71 & 1.21 & 1.24 & 1.28 \\
\hline 4 & $20 \%$ & 1.68 & 1.11 & 1.61 & 1.24 \\
\hline 5 & $25 \%$ & 1.38 & 1.17 & 1.33 & 1.37 \\
\hline 6 & $30 \%$ & 1.37 & 1.18 & 1.09 & 1.22 \\
\hline 7 & & & & \\
\hline
\end{tabular}

\subsection{SPLIT TENSILE STRENGTH ON 28TH DAY.}

Table 8.6 Split tensile strength of M30 concrete on 28th day

\begin{tabular}{|c|c|c|c|c|c|}
\hline \multirow{2}{*}{ S. no } & \multirow{2}{*}{ Percentage of glass powder } & \multicolumn{3}{|c|}{ Split tensile strength $\mathrm{N} / \mathrm{mm}^{2}$} & \multirow{2}{*}{ Average split tensile strength $\mathrm{N} / \mathrm{mm}^{2}$} \\
\hline & & Sample 1 & Sample 2 & Sample 3 & \\
\hline 1 & $0 \%$ & 1.91 & 2.03 & 1.86 & 1.93 \\
\hline 2 & $5 \%$ & 1.92 & 2.00 & 1.93 & 1.95 \\
\hline 3 & $10 \%$ & 1.97 & 2.09 & 2.07 & 2.04 \\
\hline 4 & $15 \%$ & 1.99 & 2.14 & 2.18 & 2.10 \\
\hline 5 & $20 \%$ & 2.71 & 2.23 & 2.57 & 2.49 \\
\hline 6 & $25 \%$ & 2.53 & 2.14 & 2.01 & 2.22 \\
\hline 7 & $30 \%$ & 1.88 & 1.96 & 1.91 & 1.91 \\
\hline
\end{tabular}

8.10 COMPARISON OF SPLIT TENSILE STRENGTH OF M30 CONCRETE WITH DIFF PERCENTAGE OF GLASS POWDER ON 7TH AND 28TH DAY

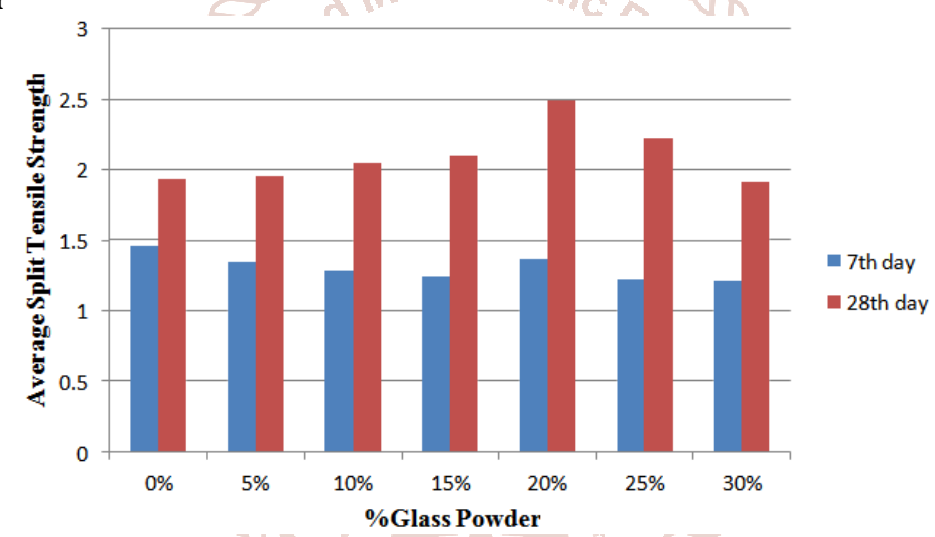

Fig 8.3 Comparison of Split tensile strength of M30 concrete on 7th and 28th day curing periods

TABLE 8.9 COMPACTION FACTOR RESULTS:

\begin{tabular}{|l|l|l|}
\hline S. NO & PERCENT GLASS POWDER & COMPACTION FACTOR \\
\hline
\end{tabular}

\begin{tabular}{|c|c|c|}
\hline 1 & 0 & 0.86 \\
\hline 2 & 5 & 0.854 \\
\hline 2 & 10 & 0.83 \\
\hline 3 & 15 & 0.826 \\
\hline 4 & 20 & 0.821 \\
\hline 5 & 25 & 0.819 \\
\hline 6 & 30 & 0.815 \\
\hline
\end{tabular}

COST ANALYSIS BASED ON PER CUBIC METRE CONCRETE:

Volume of concrete $=1 \mathrm{~m}^{3}$

Density of concrete $=2400 \mathrm{~kg} / \mathrm{m}$

Mix ratio $=1: 1.3: 2.8$

Quantity of cement in $1 \mathrm{~m} 3$ concrete $=2400 / 5.1$

$$
=470.59 \mathrm{~kg}
$$

At optimum dosage of glass powder i.e. $20 \%$

$\begin{aligned} \text { Cement saved per meter cube of concrete } & =20 \% \text { of } 470.59 \mathrm{~kg} \\ & =94.19 \mathrm{~kg} \\ \text { Amount saved per meter cube of concrete } & =94.19 \times 8 \\ & =\mathrm{Rs} 754 .\end{aligned}$




\section{CONCLUSION WORKABILITY}

As the content of glass powder increases in concrete and the cement content decreases then the workability of concrete also decreases. As there is a reduction in fineness modulus of cementitious material, quantity of cement paste available is less for providing lubricating effect per unit surface area of aggregate. Therefore, there is a restrain on the mobility.

\section{STRENGTH}

As the percentage of glass powder increases in concrete with the replacement of cement replacement of cement, strength increases up to $20 \%$ and beyond that it start decreasing. The highest percentage increase in the compressive strength was about $30 \%$ and flexural strength was about $22 \%$ at $20 \%$ replacement of glass powder with cement. The increase in strength up to $20 \%$ replacement of cement by glass powder may be due to the pozzolanic reaction of glass powder due to high silica content. Also it fills the voids in concrete and gives a dense concrete microstructure. However, beyond 20\%, the dilution effect takes over and the strength starts to drop. Thus it can be concluded that $20 \%$ is the optimum level for replacement of cement with glass powder. The strength improvement at early curing ages was slow due to pore filling effect but later it start increases. Later waste glass powder on hydration liberates sufficient amount of lime for starting the secondary pozzolanic reaction leading to more quantity of C$\mathrm{S}$-H gel getting formed.

$>$ On addition of GLP initial rate of gain of strength is low but at 28th day strength is more than the design strength.

$>$ At the level of $20 \%$ replacement of cement by glass powder, strength is higher as compare to that of normal concrete and other percentage of replacement of cement on 28th day.

$>$ The compressive strength of glass powder concrete shows an increment of about $18 \%$ at the age of 28th days at optimum level i-e $20 \%$ replacement of cement by waste glass powder.

$>$ The flexural strength of glass powder concrete shows an increment of about $27 \%$ at the age of 28 th days at optimum level i-e $20 \%$ replacement of cement by waste glass powder.

$>$ The split tensile strength of glass powder concrete shows an increment of about $29 \%$ at the age of 28th days at optimum level i-e $20 \%$ replacement of cement by waste glass powder.

$>$ Workability of concrete decreases with increase in the percentage of replacement of cement with glass powder.

$>$ As the size of GLP particle decreases in concrete the strength of concrete increases. From results it is conclude that particle size less than 75 micron get higher strength than that of particle size ranges from 90 to 150 micron.

\section{FUTURE SCOPE:}

The project work was emphasized on use of glass materials as partially replacement of cement. Further one can extend this work as follows.

$>$ The effect of glass materials on compressive strength of concrete as partially replacement of coarse aggregates and fine aggregates can be analysed and studied.

$>$ The effect of pulverised glass materials on ductility at beam column joint, durability ,fire resistant properties etc. can be analysed and studied

$>$ The glass powder and silica fume are the pozzolanic materials. Therefore compressive strength can be studied by using this materials same as partially replacement of cement in concrete. And also can be determined its optimum dosage range when concrete reaches maximum strength

\section{REFRENCES:}

[1] M.S.SHE Y "Concrete technology theory and practice" S. chand publishing a division of S. chand \& company .(ISO $9001: 2000$ company)

[2] Dhanaraj Mohan Patil, Dr. Keshav K. Sangle: "Experimental Investigation f Waste Glass Powder As Partial Replacement Of Cement In Concrete" International Journal of Advanced Technology in Civil Engineering, ISSN: $2231-5721$, Volume-2, Issue- 1, 2013

[3] Dr. G.Vijayakumar, Ms H. Vishaliny, Dr. D. Govindarajulu : "Experimental Investigation Of Waste Glass Powder As Partial Replacement Of Cement In Concrete" International Journal of Emerging echnology and dvance 5 d Engineering,2014

[4] Bhupendra Singh Shekhawat, Dr. Vanita ggarwal: "Utilisation of Waste Glass Powder in Concrete" International Journal of Innovative Research in Science, Engineering and Technology (An ISO 3297: 2007 Certified Organization) Vol. 3, Issue 7, July 2014

[5] Veena V. Bhat, N.Bhavanishankar Rao : “ Influence of glass powder on properties of concrete International Journal of Engineering trends and Technology" - Volume 16 Number 5-Oct 2015

[6] M. daway and Y. Wang : " Recycled Glass as a Partial Replacement of Cement in Structural Concrete" Electronic Journal of Structural Engineering 14(1) 2015

[7] Ashutosh Sharma : "Glass Powder - A Partial Replacement for Cement" International Journal Of Core Engineering \& Management (IJCEM) Volume 1, Issue 11, February 2015

[8] Sameer Shaikh, S. S. Bachav, D. Y. Kshirsagar " Effective utilization of Waste Glass in Concrete" (ISSN:22489622,Vol 5, Issue 12, December 2015 